\title{
Structure of the O-antigen of Salmonella O66 and the genetic basis for similarity and differences between the closely related O-antigens of Escherichia coli O166 and Salmonella O66
}

Correspondence

Lei Wang

wanglei@nankai.edu.cn

Received 17 December 2009

Revised 19 February 2010

Accepted 23 February 2010
Bin Liu, ${ }^{1,2} \dagger$ Andrei V. Perepelov, ${ }^{3} \dagger$ Dan Li, ${ }^{1,2} \dagger$ Sof'ya N. Senchenkova, ${ }^{3}$ Yanfang Han, ${ }^{1,2}$ Alexander S. Shashkov, ${ }^{3}$ Lu Feng, ${ }^{1,2,4}$ Yuriy A. Knirel ${ }^{3}$ and Lei Wang ${ }^{1,2,4,5}$

${ }^{1}$ TEDA School of Biological Sciences and Biotechnology, Nankai University, 23 Hongda Street, TEDA, Tianjin 300457, PR China

${ }^{2}$ Tianjin Key Laboratory of Microbial Functional Genomics, Tianjin 300457, PR China

${ }^{3}$ N. D. Zelinsky Institute of Organic Chemistry, Russian Academy of Sciences, 119991 Moscow, Russian Federation

${ }^{4}$ Tianjin Research Center for Functional Genomics and Biochip, Tianjin 300457, PR China

${ }^{5}$ The Key Laboratory of Molecular Microbiology and Technology, Ministry of Education, PR China

O-antigen is a component of the outer membrane of Gram-negative bacteria and is one of the most variable cell surface constituents, leading to major antigenic variability. The O-antigen forms the basis for bacterial serotyping. In this study, the O-antigen structure of Salmonella O66 was established, which differs from the known O-antigen structure of Escherichia coli 0166 only in one linkage (most likely the linkage between the $\mathrm{O}$-units) and $\mathrm{O}$-acetylation. The $\mathrm{O}$-antigen gene clusters of Salmonella $\mathrm{O} 66$ and E. coli $\mathrm{O} 166$ were found to have similar organizations, the only exception being that in Salmonella O66, the wzy gene is replaced by a non-coding region. The function of the wzy gene in E. coli $\mathrm{O} 166$ was confirmed by the construction and analysis of deletion and trans-complementation mutants. It is proposed that a functional wzy gene located outside the O-antigen gene cluster is involved in Salmonella $\mathrm{O} 66 \mathrm{O}$-antigen biosynthesis, as has been reported previously in Salmonella serogroups A, B and D1. The sequence identity for the corresponding genes between the O-antigen gene clusters of Salmonella O66 and E. coli O166 ranges from 64 to $70 \%$, indicating that they may originate from a common ancestor. It is likely that after the species divergence, Salmonella $\mathrm{O} 66$ got its specific $\mathrm{O}$-antigen form by inactivation of the wzy gene located in the $\mathrm{O}$-antigen gene cluster and acquisition of two new genes (a wzy gene and a prophage gene for $\mathrm{O}$-acetyl modification) both residing outside the $\mathrm{O}$-antigen gene cluster.

\section{INTRODUCTION}

Lipopolysaccharide (LPS), a key component of the outer membrane of Gram-negative bacteria, consists of three distinct regions: lipid $\mathrm{A}$, an oligosaccharide core and an $\mathrm{O}$ specific polysaccharide (O-antigen). The $\mathrm{O}$-antigen comprises a number of oligosaccharide repeats (O-units), which usually contain between two and eight sugar

†These authors contributed equally to this work.

Abbreviations: GalNAc, N-acetylgalactosamine; GlcNAc, N-acetyl-Dglucosamine; LPS, lipopolysaccharide; SR-type, semi-rough type.

The GenBank/EMBL/DDBJ accession number for the sequences of the E. coli $\mathrm{O} 166$ and Salmonella 066 O-antigen gene clusters are GU299794 and GU299799, respectively. residues. The O-antigen exhibits extensive variation in the types of sugar present, their arrangement within the Ounit and the linkages within and between $\mathrm{O}$-units, making LPS one of the most variable cell constituents. The Oantigen appears to be a major target of the immune system and bacteriophages. The variability of the $\mathrm{O}$-antigen provides the major basis for serotyping schemes for many Gram-negative bacteria, such as Escherichia coli and Salmonella.

$\mathrm{O}$-antigen diversity is thought to be important in allowing the various clones to present variations in surface structures that may offer a selective advantage in their specific niche (Reeves, 1992). O-antigen is also essential for the full function of bacteria and is related to bacterial 
virulence. It has been shown that the virulence of Shigella flexneri is reduced if the $\mathrm{O}$-antigen is changed (Gemski et al., 1972).

The majority of $\mathrm{O}$-antigen biosynthetic genes reside within a gene cluster that maps between the galF and gnd genes in E. coli, Salmonella and Shigella genomes. Genetic variation in the $\mathrm{O}$-antigen gene cluster contributes to a diverse array of $\mathrm{O}$-antigen forms. O-antigen biosynthetic genes fall into three main classes: (i) nucleotide sugar precursor synthesis genes, (ii) sugar transfer genes associated with $\mathrm{O}$-unit formation and (iii) $\mathrm{O}$-unit processing genes associated with the conversion of the $\mathrm{O}$-unit to $\mathrm{O}$-antigen.

The clonal species E. coli includes both commensal and pathogenic strains, which are usually identified by a combination of their $\mathrm{O}-$ and $\mathrm{H}$ - (and sometimes $\mathrm{K}-$ ) antigens. To date, $174 \mathrm{O}$-serogroups have been described for E. coli (Liu et al., 2008). Salmonella is recognized as a major pathogen of both animals and humans, and in many countries, it is the leading cause of outbreaks of food-borne infections. Forty-six O-serogroups are described for Salmonella in the Kauffmann-White serotyping scheme, in which members of each serogroup have the same basic $\mathrm{O}$-antigen structure and each serogroup is divided into serotypes based on $\mathrm{H}$-antigens.

Though E. coli and Salmonella are known to be evolutionarily closely related, previous analysis indicates that they have only a few $\mathrm{O}$-antigen structures in common (Samuel et al., 2004). Combined structural and genetic studies will improve our understanding of the relationship between the $\mathrm{O}$-antigens of E. coli and Salmonella. In this study, the O-antigen structure of Salmonella O66 was determined and compared with the related structure of $E$. coli $\mathrm{O} 166$ reported previously (Ali et al., 2007). The Oantigen gene clusters of Salmonella O66 and E. coli O166 were sequenced and analysed. A wzy mutant of E. coli O166 was constructed to characterize the gene function. The evolutionary relationship between the O-antigens of E. coli O166 and Salmonella O66 is discussed.

\section{METHODS}

Cultivation of bacteria and isolation of LPS. Salmonella O66, strain G1601, was grown to late-exponential phase in $81 \mathrm{LB}$ using a 101 fermenter (Biostat C-10, B. Braun Biotech International) under constant aeration at $37^{\circ} \mathrm{C}$ and $\mathrm{pH} 7.0$, and bacterial cells were washed and dried as described by Robbins \& Uchida (1962). Dried cells $(5 \mathrm{~g})$ were extracted with a phenol/water mixture as described by Westphal \& Jann (1965). After dialysis of combined phenol and water layers, contaminations were precipitated by adding $50 \%$ aqueous trichloroacetic acid at $4{ }^{\circ} \mathrm{C}$; the supernatant was dialysed against distilled water and lyophilized to give LPS $(0.5 \mathrm{~g})$.

Preparation and $\mathbf{O}$-deacetylation of the $\mathbf{O}$-polysaccharide. Delipidation of LPS (100 mg) was performed with aqueous $2 \%$ acetic acid $(6 \mathrm{ml})$ at $100{ }^{\circ} \mathrm{C}$ for $2 \mathrm{~h}$. The precipitate was removed by centrifugation $(13000 \mathrm{~g}, 20 \mathrm{~min})$ and the supernatant was fractionated on a Sephadex G-50 Superfine column $(56 \times 2.6 \mathrm{~cm}$; Amersham Biosciences) in $0.05 \mathrm{M}$ pyridinium acetate buffer $\mathrm{pH} 5.5$ with monitoring, using a differential refractometer (Knauer). The Opolysaccharide was obtained in a yield $\sim 30 \%$ of the LPS mass.

The O-polysaccharide $(30 \mathrm{mg}$ ) was treated with aqueous $12.5 \%$ ammonia at $37{ }^{\circ} \mathrm{C}$ for $16 \mathrm{~h}$. Ammonia was removed with a stream of air and the remaining solution was desalted on a TSK HW-40 (S) column $(90 \times 2.5 \mathrm{~cm}$; Merck $)$ in water and freeze-dried to give an $\mathrm{O}$ deacetylated polysaccharide $(25 \mathrm{mg})$.

Chemical analyses. The O-polysaccharide was hydrolysed with $2 \mathrm{M}$ trifluoroacetic acid $\left(120^{\circ} \mathrm{C}, 2 \mathrm{~h}\right)$ and the monosaccharides were identified as the alditol acetates by GLC on a Hewlett Packard 5890 chromatograph equipped with an Ultra-2 column (Agilent) using a temperature gradient of $160-290{ }^{\circ} \mathrm{C}$ at $3{ }^{\circ} \mathrm{C} \mathrm{min}{ }^{-1}$. The absolute configuration of the monosaccharides was determined by GLC of the acetylated (S)-2-octyl glycosides as described by Leontein \& Lönngren (1993).

NMR spectroscopy. Samples were deuterium-exchanged by freezedrying twice from $99.9 \% \mathrm{D}_{2} \mathrm{O}$ and then examined as solutions in $99.95 \% \mathrm{D}_{2} \mathrm{O}$ at $27{ }^{\circ} \mathrm{C}$. NMR spectra were recorded on an Avance 600 spectrometer (Bruker) using internal sodium 3-(trimethylsilyl)propionate-2,2,3,3- $\mathrm{d}_{4}\left(\delta_{\mathrm{H}} 0.00\right)$ and acetone $\left(\delta_{\mathrm{C}} 31.45\right)$ as references. Two-dimensional NMR spectra were obtained using standard Bruker software, and the Bruker TOPSPIN program was used to acquire and process the NMR data. Mixing times of 200 and $100 \mathrm{~ms}$ were used in TOCSY and ROESY experiments, respectively.

Construction of a DNase I shotgun bank, DNA sequencing and data analysis. Chromosomal DNA from E. coli and Salmonella was prepared as described previously (Bastin \& Reeves, 1995). Primers WL_1098 (5'-ATTGGTAGCTGTAAGCCAAGGGCGGTAGCGT-3') and WL_2211 (5' -CACTGCCATACCGACGACGCCGATCTGTTGCTTGG-3') (Wang \& Reeves, 1998), based on sequences from the JUMPStart site and gnd genes, respectively, were used to amplify $E$. coli O166 and Salmonella O66 O-antigen gene clusters using the expand long template PCR system (Roche). The PCR cycle used was as follows: denaturation at $94{ }^{\circ} \mathrm{C}$ for $10 \mathrm{~s}$, annealing at $60{ }^{\circ} \mathrm{C}$ for $30 \mathrm{~s}$ and extension at $68{ }^{\circ} \mathrm{C}$ for $15 \mathrm{~min}$. The PCR products were digested with DNase I and the resulting DNA fragments were cloned into pGEM-T Easy (Promega) to produce a bank using the method described previously (Wang \& Reeves, 1998). DNA sequencing was carried out by the Tianjin Biochip Corporation, using an ABI 3730 automated DNA sequencer. Sequence data were assembled and analysed as described previously (Liu et al., 2006).

Deletion and complementation of the wzy gene. The wzy gene from E. coli $\mathrm{O} 166$ was replaced by a chloramphenicol acetyltransferase (cat) gene using the RED recombination system of phage lambda (Datsenko \& Wanner, 2000; Yu et al., 2000). The cat gene was amplified by PCR from plasmid pKK232-8 (Pharmacia) using primers that bind to the $5^{\prime}$ and $3^{\prime}$ ends of the gene, and each primer carried 40 bp of E. coli O166 DNA flanking the wzy gene (upstream primer WL-30957, 5'-TGCAAATAAACATATACTTTAAATATTATAAGAGATTAGTCAGGAGCTAAGGAAGCTAA-3'; downstream primer WL-30958, 5'-GTCTCCGACGAAAAAACAAATATTTTTCACAATAACCCTCAAAAAAATTACGCCCCGC-3'). The PCR product was transformed into E. coli O166 type strain G1216 carrying plasmid pKD20, and chloramphenicol-resistant transformants were selected after induction of the RED genes according to the protocol described by Datsenko \& Wanner (2000). To complement the wzy-deficient mutants, the $w z y$ gene of E. coli O166 was amplified using primers WL-30961 (upstream primer, 5' -GGAATTCGATGTACCATATAGCAATAGCGT-3') and WL-30962 (downstream primer, 5'-CGGGATCCTTAAATACTAAAAAATGTTTTATAC- $3^{\prime}$ ), and the resulting PCR products were cloned into pUC18 to create plasmid pLW1539. Membrane preparation, SDS-PAGE and silver staining were carried 
out for visualization of the LPS, as described previously (Wang \& Reeves, 1994).

\section{RESULTS AND DISCUSSION}

\section{Structure elucidation of the 0-polysaccharide of Salmonella 066}

LPS was obtained from dried bacterial cells of Salmonella O66 by using the Westphal procedure (Westphal \& Jann, 1965) and degraded with mild acid to yield an Opolysaccharide isolated by gel-permeation chromatography on Sephadex G-50. Sugar analysis by GLC of the alditol acetates derived after full acid hydrolysis of the polysaccharide revealed glucose and galactose in the ratio $1: 2.2$, as well as $\mathrm{N}$-acetylgalactosamine (GalNAc). GLC of the acetylated glycosides with (S)-2-octanol showed that all monosaccharides have the D configuration.

The ${ }^{13} \mathrm{C}$ NMR spectrum of the O-polysaccharide (Fig. 1a) contained signals of different intensities, most likely owing to nonstoichiometric $O$-acetylation, as there was a signal for $\mathrm{CH}_{3}$ of an $\mathrm{O}$-acetyl group at $\delta$ 21.9. The ${ }^{1} \mathrm{H}$-NMR spectrum of the O-polysaccharide showed signals for one $O$-acetyl group at $\delta 2.13$ and two $N$-acetyl groups at $\delta 2.04$ and 2.06. The NMR spectra of the $O$-deacetylated polysaccharides were typical of a regular polymer. The ${ }^{13} \mathrm{C}$ NMR spectrum (Fig. 1b) showed signals for five anomeric carbons at $\delta$ 95.1-106.5, two nitrogen-bearing carbons (C-2 of two GalNAc residues) at $\delta 50.1$ and 52.5, five $\mathrm{CH}_{2} \mathrm{O}$ groups (C-6 of monosaccharides) at 61.2-62.7
(4 carbons) and 66.5 (shown by attached-proton test), other sugar carbons in the region $\delta 65.0-79.9$ and two $\mathrm{N}$ acetyl groups at $\delta$ 23.6, 23.9 (both $\mathrm{CH}_{3}$ ), 176.0 and 176.1 (both CO). The ${ }^{1} \mathrm{H}$ NMR spectrum of the $O$-deacetylated polysaccharide contained, among other things, signals for five anomeric protons at $\delta 4.45-5.16$ and two $N$-acetyl groups at $\delta 2.03$ and 2.05 .

The ${ }^{1} \mathrm{H}$ and ${ }^{13} \mathrm{C}$ NMR spectra of the $O$-deacetylated polysaccharide were assigned (Table 1 ) using $2 \mathrm{D}$ correlation spectroscopy, including ${ }^{1} \mathrm{H},{ }^{1} \mathrm{H}$ COSY, TOCSY and ${ }^{1} \mathrm{H},{ }^{13} \mathrm{C}$ HSQC experiments, and five sugar spin systems were revealed. Based on coupling constant values, the spin systems were assigned to two residues each of galactose (A and B) and GalNAc (C and D) and one residue of glucose (E). $J_{1,2}$ coupling constant values of $\sim 3 \mathrm{~Hz}$ indicated that units $\mathrm{A}, \mathrm{B}$ and $\mathrm{C}$ are $\alpha$-linked, whereas significantly larger $J_{1,2}$ values of $7-8 \mathrm{~Hz}$ showed that units $\mathrm{D}$ and $\mathrm{E}$ are $\beta$-linked.

The signals for C- 2 of unit A, C- 6 of unit B, C-3 and C-4 of unit $\mathrm{C}$ and $\mathrm{C}-3$ of unit $\mathrm{D}$ were shifted significantly downfield to $\delta 79.9,66.5,77.7,76.9$ and 76.3, respectively, compared with their positions in the corresponding nonsubstituted monosaccharides (Lipkind et al., 1988). These displacements were due to glycosylation and thus defined the glycosylation pattern in the $\mathrm{O}$-unit. The sequence of the sugar residues was determined by a $2 \mathrm{D}$ ROESY experiment, which showed inter-residue cross-peaks between the following anomeric protons and protons at the linkage carbons: A H-1/B H-6a,6b; $\mathrm{B} \mathrm{H}-1 / \mathrm{C} \mathrm{H}-4$; $\mathrm{C} \mathrm{H}-1 /$ $\mathrm{D} \mathrm{H}-3$; D H-1/A H-2; and $\mathrm{E} \mathrm{H}-1 / \mathrm{C} \mathrm{H}-3$. The sequence

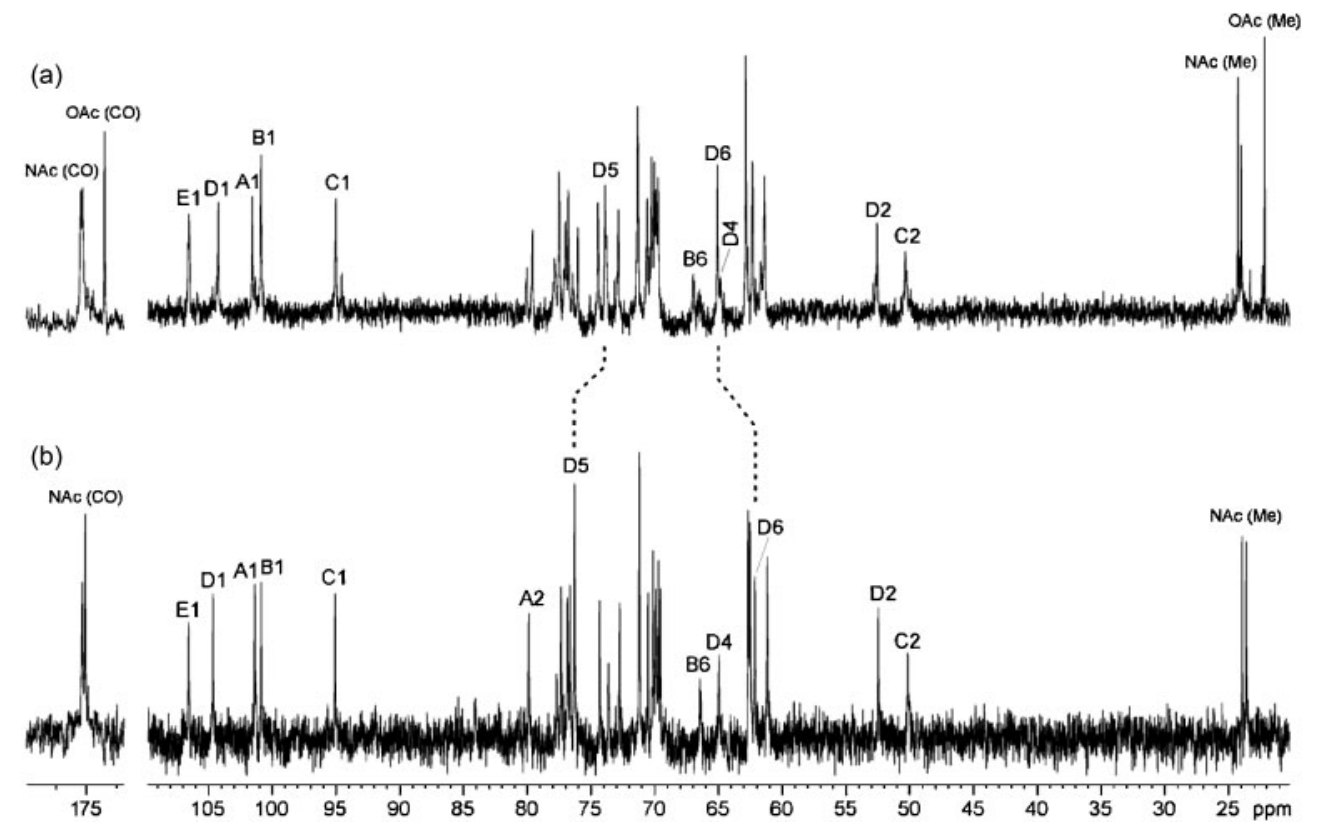

Fig. 1. ${ }^{13} \mathrm{C}$ NMR spectra $(125 \mathrm{MHz})$ of the O-polysaccharide (a) and O-deacetylated polysaccharide (b) from Salmonella O66. Numbers refer to the carbons in sugar residues denoted by letters, as shown in Table 1. 
Table 1. ${ }^{1} \mathrm{H}$ and ${ }^{13} \mathrm{C}$ NMR chemical shifts of the polysaccharides from Salmonella O66 ( $\delta$, ppm)

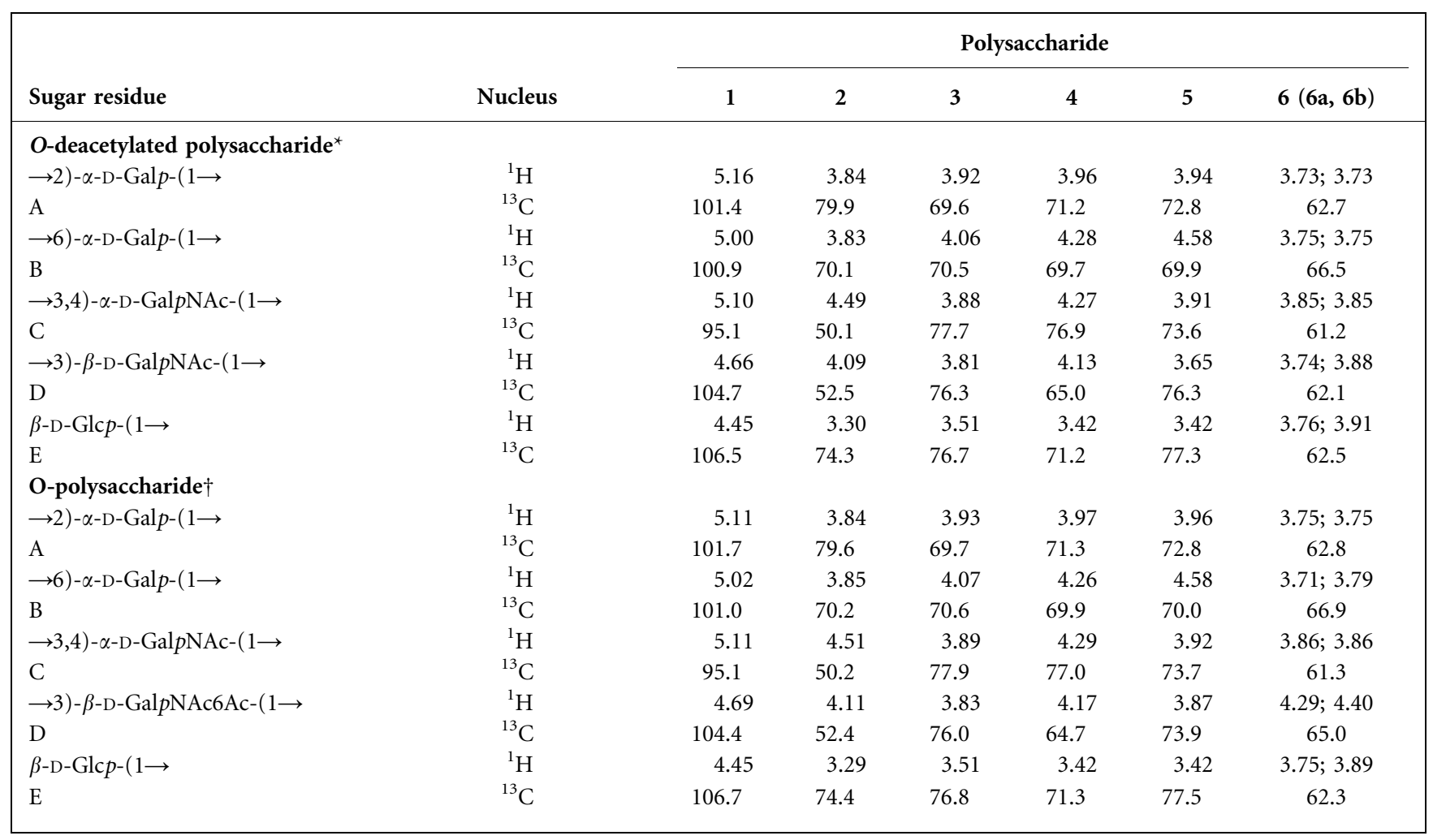

${ }^{*}$ Signals for $N$-acetyl groups are at $\delta_{\mathrm{H}} 2.03$ and $2.05 ; \delta_{\mathrm{C}} 23.6$ and $23.9(\mathrm{Me}) ; 176.0$ and $176.1(\mathrm{CO})$.

$\dagger$ Signals for an $\mathrm{O}$-acetyl group are at $\delta_{\mathrm{H}} 2.13, \delta_{\mathrm{C}} 21.9(\mathrm{Me})$ and $175.5(\mathrm{CO})$; for $N$-acetyl groups at $\delta_{\mathrm{H}} 2.04$ and $2.06, \delta_{\mathrm{C}} 23.7$ and $24.0(\mathrm{Me}), 176.2$ and $176.3(\mathrm{CO})$.

was confirmed independently by a ${ }^{1} \mathrm{H},{ }^{13} \mathrm{C}$ HMBC experiment, which showed correlations between anomeric protons and linkage carbons and vice versa (data not shown).

The position of the $\mathrm{O}$-acetyl group in the O-polysaccharide was determined by a ${ }^{1} \mathrm{H},{ }^{13} \mathrm{C}$ HSQC experiment, which showed a significant downfield displacement of $\sim 80 \%$ of the D H-6a,6b/C-6 cross-peaks from $\delta 3.74,3.88 / 62.1$ in the $O$-deacetylated polysaccharide to $\delta 4.29,4.40 / 65.0$ in the initial O-polysaccharide. This shift was evidently due to a deshielding effect of the $O$-acetyl group ( $\alpha$-effect of $O$ acetylation) and indicated $O$-acetylation of $\sim 80 \%$ unit $\mathrm{D}$ at position 6 . This conclusion was confirmed by a downfield shift by 2.9 p.p.m. and an upfield shift by 2.4 p.p.m. of the signals for C- 6 and C-5 of unit D (Fig. 1) caused by $\alpha$ - and $\beta$-effects of $O$-acetylation, respectively (Jansson et al., 1987).

Therefore, the O-polysaccharide of Salmonella O66 has structure 1, as shown in Fig. 2. A closely related Opolysaccharide of E. coli O166, whose structure (2, Fig. 2) has been elucidated previously (Ali et al., 2007), differs only in one linkage (at position 2 of Gal A in Salmonella O66 vs position 3 in E. coli O166), which is, most likely, the linkage between the O-units, and by the lack of $O$ acetylation.

\section{Characterization of the $\mathbf{0}$-antigen gene cluster of $E$. coli 0166 and confirmation of the function of the wzy gene}

A sequence of 10140 bases was obtained between the JUMPStart site and the gnd gene from E. coli O166 type strain G1216. Seven ORFs were identified, all of which have the same transcriptional direction from the JUMPStart site to the gnd gene. All of the genes were assigned functions based on their similarities to genes from available databases (Table 2).

Genes for the synthesis of the nucleotide precursors of common sugars, including Glc and Gal, are located outside the O-antigen gene cluster (Samuel \& Reeves, 2003). Therefore, only the biosynthetic gene for GalNAc was expected to be located in the $\mathrm{O}$-antigen gene cluster of $E$. coli O166. Orf7 shares $60 \%$ identity with Gne (a UDP- $N$ acetyl-D-glucosamine-4-eipmerase) of E. coli O107, which converts UDP- $N$-acetyl-D-glucosamine (-GlcNAc) to UDP-GalNAc (Wang et al., 2009). Therefore, orf7 was identified as a UDP-GlcNAc-4-epimerase gene and designated gne accordingly.

Both Wzx and Wzy are highly hydrophobic membrane proteins. Orf1 and Orf3 are the only two proteins with predicted transmembrane segments. Orf1 was predicted to 


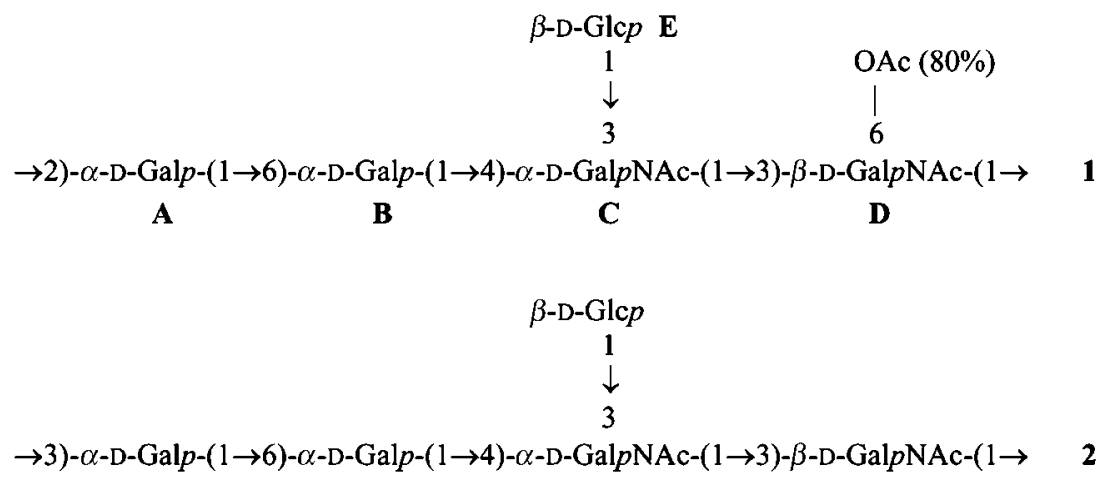

Fig. 2. Structure of the O-polysaccharides of Salmonella O66 (structure 1) and E. coli O166 (structure 2).

have 11 well-proportioned transmembrane segments, and shares $47 \%$ similarity with the putative O-antigen flippase of E. coli strain S88. Orf3 was found to have 10 predicted transmembrane segments with a large periplasmic loop of 46 aa, a typical topological characteristic of Wzy proteins (Daniels et al., 1998). Orf3 shares $48 \%$ similarity with the Wzy protein of S. boydii type 11. Therefore, orf1 and orf3 were proposed to be the $\mathrm{O}$-antigen flippase gene $(w z x)$ and $\mathrm{O}$-antigen polymerase gene ( $w z y)$, respectively, and were named accordingly.

WecA-catalysed transfer of GlcNAc-1-phosphate or GalNAc-1-phosphate to an undecaprenol phosphate carrier triggers $\mathrm{O}$-unit synthesis in E. coli, and the wecA gene is located outside the $\mathrm{O}$-antigen gene cluster (Alexander \& Valvano, 1994). Therefore, four additional glycosyltransferase genes were expected in the $\mathrm{O}$-antigen gene cluster of E. coli O166. Orf2, Orf4, Orf5 and Orf6 share 68, 61, 66 and $62 \%$ similarity to $\mathrm{WbcL}, \mathrm{WbcM}, \mathrm{WbcN}$ and $\mathrm{WbcQ}$, respectively, and all four proteins are glycosyltransferases involved in the synthesis of the LPS outer core of Yersinia enterocolitica serotype O:3 (Skurnik et al., 1999). Given these observations, orf2, orf4, orf5 and orf6 were proposed to be glycosyltransferase genes, and were named weiA, $w e i B$, weiC and weiD, respectively.

To confirm the function of wzy in E. coli O166, gene deletion followed by trans-complementation was carried out. Deletion of the $w z y$ gene in E. coli resulted in a semirough (SR-type) LPS phenotype with only one O-unit attached to the core-lipid A moiety (Daniels et al., 1998). The mutant strain $\mathrm{H} 1985$ was constructed from the E. coli O166 type strain by replacing the wzy gene with the cat gene. A comparison of the wild-type and mutant LPS by SDS-PAGE (Fig. 3) revealed that the mutant strain produced no S-type LPS, but instead produced SR-type LPS with only one O-unit attached to the core. This SRLPS phenotype was trans-complemented by introduction

Table 2. Characteristics of the ORFs in the E. coli O166 O-antigen gene cluster

\begin{tabular}{|c|c|c|c|c|c|c|c|}
\hline $\begin{array}{l}\text { Orf } \\
\text { no. }\end{array}$ & $\begin{array}{l}\text { Gene } \\
\text { name }\end{array}$ & $\begin{array}{l}\text { Position of } \\
\text { gene }\end{array}$ & $\begin{array}{c}G+C \\
\text { content } \\
(\%)\end{array}$ & Conserved domain $(s)$ & $\begin{array}{l}\text { Similar protein }(s) \text { or strain }(s) \\
\quad(\text { GenBank accession no. })\end{array}$ & $\begin{array}{l}\text { Identity/similarity } \\
\text { (\%) (no. of aa } \\
\text { overlap) }\end{array}$ & $\begin{array}{c}\text { Putative function } \\
\text { of protein }\end{array}$ \\
\hline 1 & $w z x$ & $1175 \ldots 2428$ & 27.9 & None & $\begin{array}{c}\text { Putative O-antigen flippase, E. coli } \\
\text { strain S88 (CAN87668) }\end{array}$ & $23 / 47(382)$ & O-antigen flippase \\
\hline 2 & weiA & $2421 \ldots 3230$ & 30.0 & $\begin{array}{l}\text { Glycosyltransferases group } 2 \\
\left(\text { PF00535) } E \text { value }=2.7 \mathrm{e}^{-31}\right.\end{array}$ & $\begin{array}{c}\text { WbcL, Yersinia enterocolitica } \\
\text { serotype O } 3 \text { (CAA87700) }\end{array}$ & 88/94 (289) & Glycosyltransferase \\
\hline 3 & $w z y$ & $3319 \ldots 4392$ & 27.6 & None & $\begin{array}{l}\text { Wzy, Shigella boydii type } 11 \\
\text { (AAS98031) }\end{array}$ & 23/48 (192) & $\begin{array}{l}\text { O-antigen } \\
\text { polymerase }\end{array}$ \\
\hline 4 & weiB & $4403 \ldots 5485$ & 30.7 & $\begin{array}{l}\text { Glycosyltransferases group } 1 \\
\left(\text { PF00534) } E \text { value }=5.2 \mathrm{e}^{-43}\right.\end{array}$ & $\begin{array}{c}\text { WbcM, Y. enterocolitica serotype } \\
\text { O : } 3 \text { (CAA87701) }\end{array}$ & $70 / 82(419)$ & Glycosyltransferase \\
\hline 5 & weiC & $5496 \ldots 6587$ & 33.6 & $\begin{array}{l}\text { Glycosyltransferases group } 1 \\
\quad\left(\text { PF00534) } E \text { value }=2 \mathrm{e}^{-42}\right.\end{array}$ & $\begin{array}{c}\text { WbcN, Y. enterocolitica serotype } \\
\text { O }: 3 \text { (CAA87702) }\end{array}$ & $62 / 75(370)$ & Glycosyltransferase \\
\hline 6 & weiD & $6574 \ldots 7650$ & 33.1 & $\begin{array}{l}\text { Glycosyltransferases group } 1 \\
\left(\text { PF00534) } E \text { value }=6.6 \mathrm{e}^{-25}\right.\end{array}$ & $\begin{array}{c}\text { WbcQ, Y. enterocolitica serotype } \\
\text { O }: 3 \text { (CAA87705) }\end{array}$ & & Glycosyltransferase \\
\hline 7 & gne & $7699 \ldots 8712$ & 34.2 & $\begin{array}{c}\text { NAD-dependent epimerase/ } \\
\text { dehydratase family (PF01370) } \\
E \text { value }=6.1 \mathrm{e}^{-149}\end{array}$ & Gne, E. coli O107 (ACH97137) & $60 / 78(336)$ & $\begin{array}{l}\text { UDP-GlcNAc-4- } \\
\text { epimerase }\end{array}$ \\
\hline
\end{tabular}




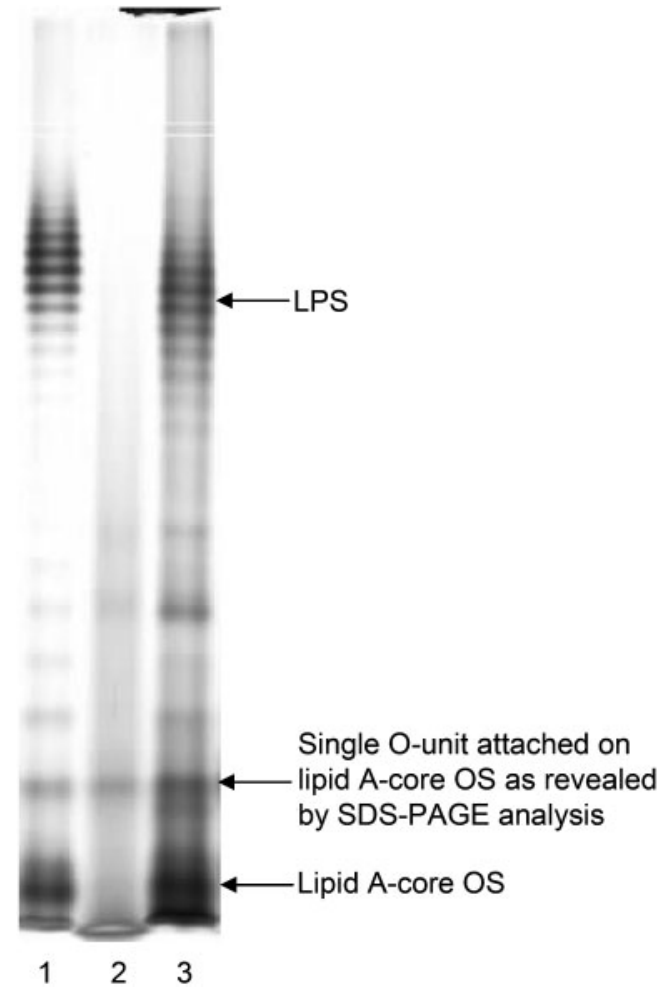

Fig. 3. SDS-PAGE analysis of deletion and trans-complemented wzy gene mutants of $E$. coli $\mathrm{O} 166$. Membrane extracts were run on SDS-PAGE gels and visualized by silver staining. Lane 1, strain G1216 (E. coli O166 type strain); lane 2, strain H1985 (G1216 lacking the wzy gene); lane 3, strain $\mathrm{H} 1986$ (H1985 containing plasmid pLW1539 carrying the E. coli O166 wzy gene).

of plasmid pLW1539 containing the wzy gene. SDS-PAGE showed that the ability to produce an S-type LPS with a long-chain O-polysaccharide was restored in the transcomplemented strain (Fig. 3). These data confirmed the function of the wzy gene in E. coli O166, as well as the identity of the E. coli O166 O-antigen gene cluster.

However, it is noted that the LPS modality for the transcomplemented strain slightly changed. The number of $\mathrm{O}$ - units attached to the core-lipid A has a characteristic modal distribution which is regulated by the chain length determinant gene $w z z$ located between gnd and his (Franco et al., 1998). The interaction and the balance between Wzy and Wzz is suggested to be important in determining the distribution of the repeat unit length (Bastin et al., 1993; Daniels et al., 1998). It is likely that the deletion and transcomplementation of the wzy gene in E. coli O166 affected the ratio of Wzy and Wzz, resulting in a decreased modal chain length.

\section{Genetic relationship between the 0 -antigen gene clusters of E. coli 0166 and Salmonella 066}

To elucidate the genetic basis for the structural similarities between the O-antigens of E. coli $\mathrm{O} 166$ and Salmonella O66, the O-antigen gene cluster of Salmonella O66 was also sequenced and compared with that of E. coli O166. These two genomic regions contained the majority of the same genes and shared a DNA identity of between 64 and $70 \%$ (Fig. 4). All genes in the O-antigen gene cluster of Salmonella O66 were assigned the same functions as the corresponding genes in E. coli O166. The only exception was that there was an $874 \mathrm{bp}$ non-coding region between the weiA and weiB genes in Salmonella O66, while the wzy gene was present in this location in E. coli O166 (Fig. 4). Therefore, no $\mathrm{O}$-antigen polymerase gene is present in the O-antigen gene cluster of Salmonella O66.

In Salmonella serogroups A, B and D1, the wzy genes responsible for the linkage between $\mathrm{O}$-units are not located in the O-antigen gene cluster; instead they are mapped far from the O-antigen gene cluster in the Salmonella genome (Wang et al., 2002). Since the Salmonella O66 type strain produces normal LPS, it is highly likely that this strain has a functional $w z y$ gene for the $\beta 1 \rightarrow 2$ linkage outside the Oantigen gene cluster. The functional wzy gene of Salmonella O66 may be located and identified by whole-genome sequencing, which will be the subject of future study. It is possible that the ancestor of the O-antigen gene cluster of Salmonella O66 had an intact $w z y$ gene for the $\beta 1 \rightarrow 3$ linkage located between the weiA and weiB genes, which became redundant when the bacteria acquired a new wzy

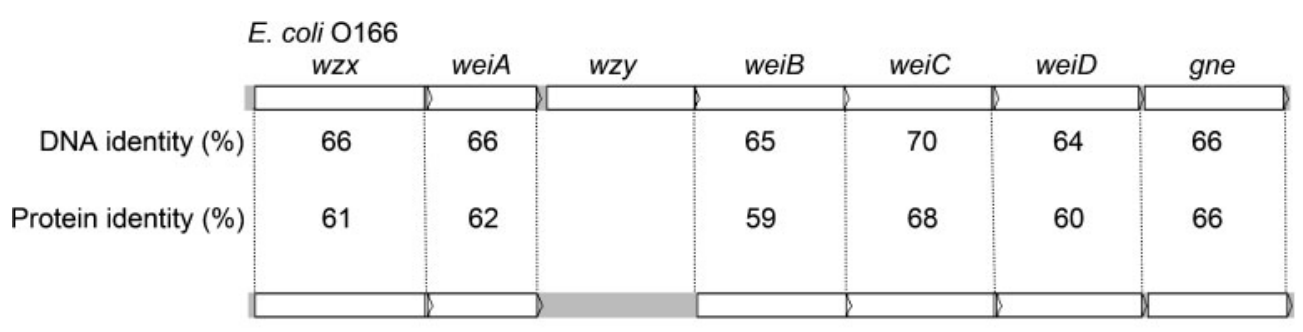

Salmonella O66

Fig. 4. Comparison of the O-antigen gene clusters of E. coli $\mathrm{O} 166$ and Salmonella O66. The non-coding region is indicated by a shaded area. 
gene. The substantial degradation of the $w z y$ gene sequence between the weiA and weiB genes in Salmonella O66 suggests that the introduction of the new wzy gene into the Salmonella O66 genome occurred a long time ago.

The genetic similarity between the $\mathrm{O}$-antigen gene clusters of E. coli O166 and Salmonella O66 is consistent with the structural similarity between their $\mathrm{O}$-antigens. Three cases are known in which the $\mathrm{O}$-antigen structures are identical in E. coli and Salmonella: E. coli O55 and Salmonella O50, E. coli O157 and Salmonella O30, and E. coli O111 and Salmonella O35 (Samuel et al., 2004). Salmonella O :6,14 has been recently reported to share an O-unit backbone with the E. coli O77 group (Wang et al., 2007). E. coli and Salmonella appear to have diverged about 140 million years ago, and $93 \%$ of E. coli and Salmonella housekeeping genes exhibit levels of identity between 76.3 and $100 \%$ (Sharp, 1991). A comparison between the O-antigen gene clusters of E. coli and Salmonella strains displaying identical O-antigen structures indicates that paired gene clusters share an obvious similarity, which is close to the lower end of the range for housekeeping genes (Samuel et al., 2004; Wang et al., 2007). These data imply that each pair of E. coliSalmonella-related gene clusters possibly originates from a common ancestor which then diverged at a higher rate than the housekeeping genes under consistent selection pressure (Samuel et al., 2004; Wang et al., 2007). The similarity level between the $\mathrm{O}$-antigen gene clusters of E. coli O166 and Salmonella O66 is similar to that previously found for other pairs of E. coli-Salmonella-related gene clusters. Therefore, we propose that the E. coli O166 and Salmonella O66 Oantigen gene clusters also have a common ancestor. After the species divergence, Salmonella O66 acquired a new wzy gene and a prophage gene for $O$-acetyl modification, both of which were located outside the $\mathrm{O}$-antigen gene cluster, and the original wzy gene in the $\mathrm{O}$-antigen gene cluster was lost over time. The resulting $\mathrm{O}$-antigen structure, which is specific for Salmonella O66, may have aided adaptation of this organism to its environmental niche.

\section{ACKNOWLEDGEMENTS}

This work was supported by the Russian Foundation for Basic Research (Projects 08-04-01205 and 08-04-92225-NNSF), the Tianjin Municipal Special Fund for Science and Technology Innovation Grant 05FZZDSH00800, the National Natural Science Foundation of China (NSFC) Key Programs Grants 30530010 and 20536040, the Chinese National Science Fund for Distinguished Young Scholars (30788001), NSFC General Program Grant 30670038, 30870078, 30771175 and 30900041, the National 863 Program of China Grants 2006AA020703 and 2006AA06Z409, the National 973 Program of China Grant 2009CB522603, and National Key Programs for Infectious Diseases of China 2008ZX10004-002, 2008ZX10004-009 and 2009ZX10004-108.

\section{REFERENCES}

Alexander, D. C. \& Valvano, M. A. (1994). Role of the $r f e$ gene in the biosynthesis of the Escherichia coli O7-specific lipopolysaccharide and other O-specific polysaccharides containing $\mathrm{N}$-acetylglucosamine. J Bacteriol 176, 7079-7084.

Ali, T., Weintraub, A. \& Widmalm, G. (2007). Structural determination of the O-antigenic polysaccharide from Escherichia coli O166. Carbohydr Res 342, 274-278.

Bastin, D. A. \& Reeves, P. R. (1995). Sequence and analysis of the O antigen gene ( $r f b$ ) cluster of Escherichia coli O111. Gene 164, 17-23.

Bastin, D. A., Brown, P. K., Haase, A., Stevenson, G. \& Reeves, P. R. (1993). Repeat unit polysaccharides of bacteria: a model for polymerisation resembling that of ribosomes and fatty acid synthetase, with a novel mechanism for determining chain length. Mol Microbiol 7, 725-734.

Daniels, C., Vindurampulle, C. \& Morona, R. (1998). Overexpression and topology of the Shigella flexneri O-antigen polymerase (Rfc/Wzy). Mol Microbiol 28, 1211-1222.

Datsenko, K. A. \& Wanner, B. L. (2000). One-step inactivation of chromosomal genes in Escherichia coli K-12 using PCR products. Proc Natl Acad Sci U S A 97, 6640-6645.

Franco, A. V., Liu, D. \& Reeves, P. R. (1998). The Wzz (Cld) protein in Escherichia coli: amino acid sequence variation determines $\mathrm{O}$ antigen chain length specificity. J Bacteriol 180, 2670-2675.

Gemski, P., Jr, Sheahan, D. G., Washington, O. \& Formal, S. B. (1972). Virulence of Shigella flexneri hybrids expressing Escherichia coli somatic antigens. Infect Immun 6, 104-111.

Jansson, P.-E., Kenne, L. \& Schweda, E. (1987). Nuclear magnetic resonance and conformational studies on monoacetylated methyl D-gluco- and D-galacto-pyranosides. J Chem Soc Perkin 1 2, 377-383.

Leontein, K. \& Lönngren, J. (1993). Determination of the absolute configuration of sugars by gas-liquid chromatography of their acetylated 2-octyl glycosides. Methods Carbohydr Chem 9, 87-89.

Lipkind, G. M., Shashkov, A. S., Knirel, Y. A., Vinogradov, E. V. \& Kochetkov, N. K. (1988). A computer-assisted structural analysis of regular polysaccharides on the basis of ${ }^{13} \mathrm{C}$-n.m.r. data. Carbohydr Res 175, 59-75.

Liu, B., Senchenkova, S. N., Feng, L., Perepelov, A. V., Xu, T., Shevelev, S. D., Zhu, Y., Shashkov, A. S., Zou, M. \& other authors (2006). Structural and molecular characterization of Shigella boydii type $16 \mathrm{O}$ antigen. Gene 380, 46-53.

Liu, B., Knirel, Y. A., Feng, L., Perepelov, A. V., Senchenkova, S. N., Wang, Q., Reeves, P. R. \& Wang, L. (2008). Structure and genetics of Shigella O antigens. FEMS Microbiol Rev 32, 627-653.

Reeves, P. R. (1992). Variation in O-antigens, niche-specific selection and bacterial populations. FEMS Microbiol Lett 79, 509-516.

Robbins, P. W. \& Uchida, T. (1962). Studies on the chemical basis of the phage conversion of $\mathrm{O}$-antigens in the E-group Salmonella. Biochemistry 1, 323-335.

Samuel, G. \& Reeves, P. (2003). Biosynthesis of O-antigens: genes and pathways involved in nucleotide sugar precursor synthesis and $\mathrm{O}-$ antigen assembly. Carbohydr Res 338, 2503-2519.

Samuel, G., Hogbin, J. P., Wang, L. \& Reeves, P. R. (2004). Relationships of the Escherichia coli O157, O111, and O55 O-antigen gene clusters with those of Salmonella enterica and Citrobacter freundii, which express identical O antigens. J Bacteriol 186, 65366543.

Sharp, P. M. (1991). Determinants of DNA sequence divergence between Escherichia coli and Salmonella typhimurium: codon usage, map position, and concerted evolution. J Mol Evol 33, 23-33.

Skurnik, M., Venho, R., Bengoechea, J. A. \& Moriyon, I. (1999). The lipopolysaccharide outer core of Yersinia enterocolitica serotype O:3 is required for virulence and plays a role in outer membrane integrity. Mol Microbiol 31, 1443-1462. 
Wang, L. \& Reeves, P. R. (1994). Involvement of the galactosyl-1phosphate transferase encoded by the Salmonella enterica $r f b P$ gene in O antigen subunit processing. J Bacteriol 176, 4348-4356.

Wang, L. \& Reeves, P. R. (1998). Organization of Escherichia coli $\mathrm{O} 157 \mathrm{O}$ antigen gene cluster and identification of its specific genes. Infect Immun 66, 3545-3551.

Wang, L., Andrianopoulos, K., Liu, D., Popoff, M. Y. \& Reeves, P. R. (2002). Extensive variation in the $\mathrm{O}$-antigen gene cluster within one Salmonella enterica serogroup reveals an unexpected complex history. J Bacteriol 184, 1669-1677.

Wang, W., Perepelov, A. V., Feng, L., Shevelev, S. D., Wang, Q., Senchenkova, S. N., Han, W., Li, Y., Shashkov, A. S. \& other authors (2007). A group of Escherichia coli and Salmonella enterica $\mathrm{O}$ antigens sharing a common backbone structure. Microbiology 153, 2159-2167.
Wang, Q., Perepelov, A. V., Feng, L., Knirel, Y. A., Li, Y. \& Wang, L. (2009). Genetic and structural analyses of Escherichia coli $\mathrm{O} 107$ and $\mathrm{O} 117 \mathrm{O}$-antigens. FEMS Immunol Med Microbiol 55, 47-54.

Westphal, O. \& Jann, K. (1965). Bacterial lipopolysaccharides. Extraction with phenol-water and further applications of the procedure. In Methods in Carbohydrate Chemistry 5, pp. 83-91. Edited by R. L. Whistler. New York, London: Academic Press.

Yu, D., Ellis, H. M., Lee, E. C., Jenkins, N. A., Copeland, N. G. \& Court, D. L. (2000). An efficient recombination system for chromosome engineering in Escherichia coli. Proc Natl Acad Sci U S A 97, 59785983.

Edited by: D. L. Gally 